ORIGINAL ARTICLE

\title{
Involvement of Enterobacter cloacae in the mortality of the fish, Mugil cephalus
}

\author{
V. Thillai Sekar, T.C. Santiago, K.K. Vijayan, S.V. Alavandi, V. Stalin Raj, J.J.S. Rajan, M. Sanjuktha \\ and N. Kalaimani
}

Aquatic Animal Health Division, Central Institute of Brackishwater Aquaculture, Chennai, India

\section{Keywords}

cationic factor, Ent. cloacae, enteric pathogen, M. cephalus, 16S rRNA.

\section{Correspondence}

Thairyam C. Santiago, Principal Scientist and Head, Aquatic Animal Health Division, Central Institute of Brackishwater Aquaculture, 75, Santhome High Road, Chennai 600 028, India. E-mail: santiagotc1@yahoo.co.in

2007/0191: received 3 February 2008, revised 10 March 2008 and accepted 11 March 2008

doi:10.1111/j.1472-765X.2008.02365.x

\begin{abstract}
Aims: To identify the causative agent of the mortality in the fish, Mugil cephalus, in Muttukadu lagoon.

Methods and Results: An enteric bacterium from the kidneys of moribund fish M. cephalus, was isolated and identified as Enterobacter cloacae (MK). Mugil cephalus was experimentally infected by this isolate and was re-isolated from the kidneys of the moribund fish. Enterobacter cloacae isolates from the lagoon water (MW1, MW2 and reference strain ATCC 13047) and the reference strain were not able to induce similar pathogenesis. The putative factor imparting pathogenicity to the MK isolate was identified as a cationic molecule, which migrated towards the cathode on agarose gel electrophoresis.

Conclusions: The Ent. cloacae (MK) isolate harbouring a cationic factor was the causative agent for the mortality of M. cephalus, found in Muttukadu lagoon.

Significance and Impact of the Study: This study reveals that human enteric bacteria MK which is considered as nonpathogenic to fish, may become pathogenic to fish when it harbours this cationic factor. This cationic factor is found to be pathogenic to the fish M. cephalus leading to mortality. It was also found to be pathogenic to mice. Therefore, the shuttling of Ent. cloacae, harbouring cationic factor, between human and fish may be of human health importance.
\end{abstract}

\section{Introduction}

Enterobacter cloacae, an enteric bacterium that belongs to the family Enterobacteriaceae, is widely distributed in nature. It is found in faeces of humans and animals, water, soil, plants, plant materials, insects and dairy products (Davidson et al. 2000; Neto et al. 2003). It has been recognized as an important human pathogen because of its ability to develop resistance to antibiotics (Gaston 1988). Further, it has also been reported as an opportunistic pathogen in humans (Flynn et al. 1987; Gaston 1988; Breathnach et al. 2006; Kanemitsu et al. 2007) and other organisms such as fish (Troast 1975; Hansen et al. 1990) and insects (Sanders and Sanders 1997).

Fish inhabiting contaminated water bodies were reported to be infected with enteric bacterial species (Janssen and Meyers 1968; Aoki et al. 1973). Antibodies against E. coli and Ent. cloacae have been detected from brown bull head catfish inhabiting coliform-contaminated waters, suggesting that the fish has been infected by these bacteria (Troast 1975). Hansen et al. (1990) have isolated Ent. agglomerans from the kidney of infected dolphin fish, Coryphaena hippurus L., showing that this enteric bacterium is pathogenic to fish. Enteric bacteria are not the normal flora in the intestinal tract of fish and hence their presence in the infected fish may be the result of the association of fish with the polluted waters (Geldreich and Clarke 1966). Therefore, the infection of fish by these microbes has been related to the feeding habits of fish. For example, the bacterial infections in the bottom feeding brown bull head catfish might probably because of its habit of ingesting the human flocculation deposits containing bacteria (Troast 1975). This may be true for other bottom feeders such as Mugil cephalus, reported in this study.

The present study reports the association of enteric bacteria with the mortality of M. cephalus, in the Muttukadu lagoon. External or internal parasitic infestation has not 
been observed. An enteric bacterium, identified as Ent. cloacae (MK) has been isolated from the kidneys of moribund fish. We have experimentally infected M. cephalus with the MK isolate by bath challenge. MK has been re-isolated from the kidneys of moribund fish. Enterobacter cloacae, isolated from the Muttukadu lagoon waters (MW1, MW2) and the ATCC13047 strain have not induced mortality in M. cephalus. MK which has induced mortality harbours a cationic factor. Purified cationic factor has also induced mortality.

\section{Materials and methods}

\section{Isolation of bacteria from moribund fish}

There was an incidence of selective mortality of M. cephalus, in the lagoon of Muttukadu, Chennai, India. Moribund M. cephalus caught from the lagoon were transported alive to the field laboratory within $10 \mathrm{~min}$ and kept in fibreglass tanks containing sand filtered bore well water with continuous aeration. Randomly chosen five lethargic moribund fish were killed and wiped with absolute alcohol to prevent surface micro-flora contamination. The kidneys were dissected out from these fish aseptically. It was swab inoculated on to Trypticase soy agar (TSA) supplemented with $1 \%$ $\mathrm{NaCl}$, TCBS (thiosulfate citrate bile salt sucrose agar) agar and MacConkey agar plates. TSA and TCBS agar plates were incubated at $30^{\circ} \mathrm{C}$, while MacConkey agar plates were incubated at $37^{\circ} \mathrm{C}$ for $48 \mathrm{~h}$. Colonies were subcultured for pure culture isolation. Bacterial colonies were identified according to the biochemical identification keys of Practical Medical Microbiology, 14th edn, edited by Collee et al. (1996).

\section{S rRNA amplification and sequencing}

Bacterial isolates were grown in nutrient broth supplemented with $1 \% \mathrm{NaCl}$ overnight at $37^{\circ} \mathrm{C}$. The genomic DNA was extracted from the isolates as described by Ausubel et al. (1987). A fragment of the 16S rRNA gene was amplified using primers fD1 [5'-AGAGTTTGATCCTGGCTCAG-3'; positions 7-26 in Escherichia coli (Brosius et al. 1981)] and rP2 (5'-ACGGCTACCTTGTTACGACTT-3'; positions 1513-1494) as described previously (Weisburg et al. 1991). Amplification was performed in a thermal cycler (Eppendorf Master cycler gradient; Eppendorf, Hamburg, Germany), using the following programme: 1 cycle of $94^{\circ} \mathrm{C}$ for $5 \mathrm{~min}, 35$ cycles of $94^{\circ} \mathrm{C}$ for $1 \mathrm{~min}, 58^{\circ} \mathrm{C}$ for $1 \mathrm{~min}$ and $72^{\circ} \mathrm{C}$ for $1 \mathrm{~min}$ and a final cycle of $72^{\circ} \mathrm{C}$ for $5 \mathrm{~min}$. Amplified products were checked by electrophoresing through $1.5 \%$ agarose gel in TBE (Tris-borate EDTA) buffer. Products were purified using a Qiagen Gel purification kit and the amplified products were sequenced (Microsynth, Balgach, Germany). The amplified 16S rRNA sequences were BLAST analysed.

\section{Experimental infection of fish by Ent. cloacae}

Enterobacter cloacae isolates (MK, MW1, MW2 and ATCC 13047) were used for experimental infection in M. cephalus, by bath challenge (Nordmo et al. 1997). One hundred and sixty numbers of $M$. cephalus with an average body weight of $10-15 \mathrm{~g}$ were taken and equally distributed in 16 troughs, each containing $10 \mathrm{l}$ of sand-filtered bore well water. These 16 troughs were divided into four sets of four each. To each set, one of the above bacterial (MK, MW1, MW2 and ATCC 13047) culture suspensions was added to a final cell density of $8.6 \times 10^{5}, 8.6 \times 10^{6}$ and $8.6 \times 10^{7}$ cells $\mathrm{ml}^{-1}\left(1\right.$ O.D. $\left.600=5 \times 10^{8}\right)$. One trough from each batch was kept as control and maintained separately. Fish were kept in the bacterial suspension for $1 \mathrm{~h}$ with aeration. Thereafter, each batch of fish was transferred to a fibreglass tank each containing $100 \mathrm{l}$ of fresh sand-filtered bore well water with aeration. Experiment was conducted in triplicate. Salinity and temperature of the water were maintained at $28 \mathrm{ppt}$ and at $30^{\circ} \mathrm{C}$, respectively, throughout the experimental period of 15 days. Approximately $70 \%$ of the water was exchanged every morning and the fish were fed pellet feed. The fish were observed for lethargy, lack of feeding and mortality for 15 days from the day of bathing. Kidney samples were taken from moribund fish for histopathological examination.

\section{Purification of cationic factor}

Cationic factor was isolated and purified from MK isolate in large scale by caesium chloride gradient ultra-centrifugation following the procedures of Birnboim and Doly (1979) and Ish-Horowicz and Burke (1981). The cationic factor appeared as a band just above the plasmid. Inserting an 18-gauge hypodermic needle into the tube the cationic complex band was taken out and purified. The purity of the cationic factor was checked by observing its migration towards the cathode in $1 \%$ agarose gel.

\section{Pathogenesis of cationic factor in fish}

Forty numbers of $M$. cephalus with 10-15 g body weight were divided into four groups of 10 each (three experimental and one control). The cationic factor at a concentration of $15,6.5$ and $0.65 \mu \mathrm{g} \mathrm{g}^{-1}$ body weight in $50 \mu \mathrm{l}$ volume of TE (Tris-EDTA) buffer was injected intramuscularly into experimental fish and $50 \mu \mathrm{l}$ of TE buffer was 
given to the control group. Each batch of fish was maintained in fibreglass tanks containing 1001 fresh sand filtered bore well water with aeration as above. The experiment was conducted in triplicate. The fish were observed for lethargy, lack of feeding and mortality for 15 days from the day of injection. Kidney samples were taken from moribund fish for histopathological examination.

\section{Results}

Isolation and characterization of the bacteria from grey mullets

Bacterial colonies from the kidney swab of the moribund fish were of identical morphotype. Colonies were observed in MacConkey agar and TSA plates and there was no growth on TCBS agar plates. The colonies were pink, mucoid, round, raised and regular in MacConkey agar. The biochemical tests revealed that they were Gram- negative motile rods, catalase positive but oxidase negative and produced copious gas from glucose. They utilized glucose and sucrose or lactose; as a result, both the butt and the slant were changed to yellow in triple sugar iron agar. They were negative for $\mathrm{H}_{2} \mathrm{~S}$ production. They were positive to ornithine decarboxylase and arginine dihydrolase but negative to lysine decarboxylase and urease. These results could discriminate Ent. cloacae isolates from Klebsiella spp. Amplified 16S rRNA gene from this isolate was sequenced and BLAST analysed. BLAST analysis revealed 100\% match with the Ent. cloacae (GenBank Acc. No. EU491518). Both the biochemical analysis and the sequence analysis confirmed that this isolate belongs to Ent. cloacae species.

\section{Experimental infection of fish by Ent. cloacae isolates}

Out of four Ent. cloacae isolates tested, only the Ent. cloacae $(\mathrm{MK})$, isolated from the kidney samples of moribund Indian grey mullets, was found to induce lethargy, reduced feeding and $100 \%$ mortality in mullets within 5 days after the bath challenge at a cell density of $8 \cdot 6 \times 10^{7}$. Ninety per cent mortality within 6 days at a cell density of $8.6 \times 10^{6}$ and $40 \%$ mortality within 7 days at $8.6 \times 10^{5}$ cell density were observed. The other isolates MW1, MW2 and ATCC 13047 were not able to induce mortality in the experimental animals even at a cell density of $8.6 \times 10^{7}$. The MK was re-isolated from the kidney tissues of experimentally infected moribund fish by swab inoculation on to MacConkey agar plates. The re-isolated $\mathrm{MK}$ isolate was able to experimentally infect M. cephalus. Histopathology of the kidney tissues showed severe cellular damages similar to that of the wild-type infection (Fig. 1b). Other three isolates, MW1, MW2 and ATCC 13047, could not induce kidney damage and mortality in the experimental fish.

\section{Identification of a cationic factor in MK isolate}

Chromosomal DNA was extracted for the PCR amplification of $16 \mathrm{~S}$ rRNA gene from the Ent. cloacae isolates (MK, MW1, MW2 and ATCC 13047) used in this study. When the chromosomal DNA preparation of these isolates was electrophoresed through $1 \%$ agarose gels, a cathode moving molecular factor was identified only in the MK isolate (Fig. 2). Such a cationic factor was not observed in Ent. cloacae isolates (MW1, MW2 and ATCC 13047). To rule out the possibility that this cationic factor was an artefact, different methods of DNA extraction such as CTAB (cetyl trimethylammonium bromide) method were used. All the preparations showed the presence of the cationic factor in MK isolate, whereas the other isolates did not reveal the presence of the cationic factor (Fig. 2). The MK isolate harbouring this cationic factor was pathogenic to fish.

\section{Pathogenesis of cationic factor in fish}

As the cationic factor was present only in MK isolate, experiments were conducted to investigate the involvement of this cationic factor in infection. The fish of the first group which received $15 \mu \mathrm{g}$ cationic factor $\mathrm{g}^{-1}$ body weight showed lethargy, reduced feeding and mortality $(100 \%)$ within 6 days. The second group which received $6.5 \mu \mathrm{g} \mathrm{g}^{-1}$ body weight showed $50 \%$ mortality preceded by lethargy and reduced feeding within 11 days postinjec-

Figure 1 Fish kidney showing extensive damage to the tubules. (a) Kidney tubules of control fish. (b) Damaged kidney tubules of the bacteria-treated fish. (c) Damaged kidney tubules of the cationic factor-treated fish.
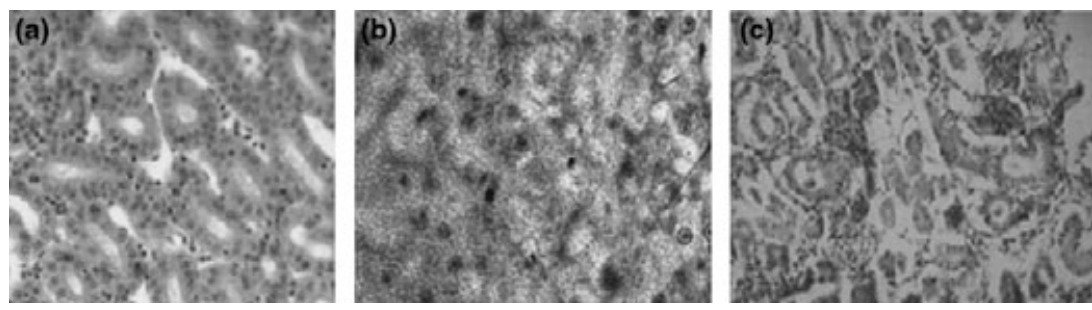


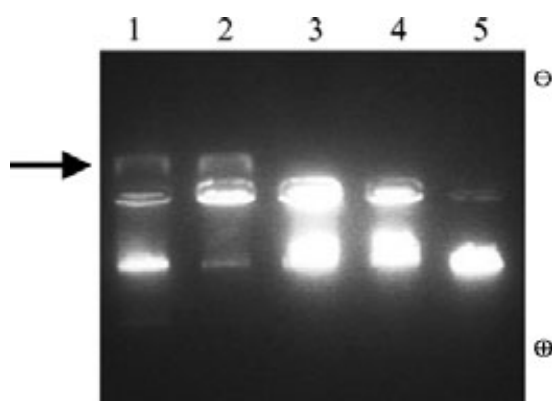

Figure 2 Electrophoretic mobility of cationic factor. Presence of cationic factor in the chromosomal DNA preparations extracted from Ent. cloacae by phenol chloroform method (lane 1) and CTAB method (lane 2). Chromosomal DNA preparations using phenol chloroform method from MW1 (lane 3), MW2 (lane 4) and Ent. cloacae (ATCC 13047) (lane 5) showing the absence of cationic factor. Symbol $\oplus$ indicates anode and $\ominus$ indicates cathode. Arrow indicates cationic factor.

tion. The remaining fish in this group did not show any of these symptoms or mortality throughout the experimental period. There was no lethargy, reduced feeding and mortality in the third group of fish, which was given with $0.65 \mu \mathrm{g} \mathrm{g}^{-1}$ body weight within the experimental period of 15 days. Control did not show any of these symptoms and mortality. Histopathology of the kidney of the affected fish showed extensive damage in the tubules when compared with the control (Fig. 1c).

\section{Discussion}

Muttukadu lagoon is inhabited by a variety of fish such as M. cephalus, Lates calcarifer, Chanos chanos and Oreochromis mosambicus. There was an incidence of selective mortality in $M$. cephalus, a bottom feeder. This water body is frequently polluted by the discharge of city sewer. Careful examination revealed the absence of external or internal parasitic infestation. The present study has aimed at investigating the causative agent involved in the mortality of this fish. One of the plausible causative factors for the selective mortality might be enteric bacterial infection, because of the human faecal contamination of the lagoon (Troast 1975). Kidney swabs has revealed that the fish have been infected by a single species of human enteric bacteria Ent. cloacae (MK). Members of human enteric bacteria are not native to the intestinal microflora of the fish $M$. cephalus and hence their association with this fish may be due to their abundance in the environment in which they inhabit (Hansen et al. 1990; Nieto and Lopez 1990; Vigneulle and Laurensin 1995). Escherichia coli and Ent. cloacae have been shown to have possible involvement in the infection of fish (Troast 1975). Therefore, it is likely that
MK may also be involved in inducing mortality in the present instance. This assumption was confirmed by the experimental infection of $M$. cephalus by bath challenge. Bath challenge was used in this study because of the efficiency in facilitating the entry of bacteria into the host (Nordmo et al. 1997). Further, this method simulates the natural association of bacteria with the host in the lagoon environment. The re-isolation of $\mathrm{MK}$ from the experimentally infected fish kidneys and the observation of histopathological changes in the kidney tubules (Fig. 1b,c) revealed that $\mathrm{MK}$ is the causative agent of this selective mortality observed in M. cephalus.

Most of the pathogenic enteric bacteria produce virulence-associated factors such as somatic antigens, adhesins, serum resistance, lipopolysaccharides, colicins, siderophores and haemolysins (Podschun and Ullmann 1998). Many of these factors are able to penetrate the epithelial layers of the intestinal mucosa and facilitate pathogenic process. Extra-cellular protein is also implicated in virulence and pathogenicity of enteric bacteria (Tan et al. 2002). Recently, haemolysin and leucotoxins have been isolated from these bacteria, which are associated with the disease process (Albesa et al. 2000; Barnes et al. 2001; Paraje et al. 2005). But none of these four isolates revealed the presence of any of these protein factors in SDS-PAGE (data not shown). Interestingly, when the chromosomal DNA preparations were electrophoresed in agarose gels, a cathode moving bizarre factor has been observed in MK. This factor was not present in other isolates. To our knowledge, such a cationic factor has not been reported thus far from any bacteria (Fig. 2). Our results have established that this is not a procedural artefact.

As this cationic factor was present only in the pathogenic isolate $\mathrm{MK}$, it was presumed that this factor might be associated with the pathogenesis in fish. We tested this hypothesis by experimental infection studies. Our studies show that the cationic factor is pathogenic to fish. The histopathology of the kidneys of the cationic factor-treated fish revealed marked changes in the tubules (Fig. 1c). This is similar to the pathological changes induced by the MK. It has been observed that only the $\mathrm{MK}$ isolate harbouring the cationic factor is able to induce mortality, whereas the other three isolates (MW1, MW2 and ATCC 13047) lacking this cationic factor is not. As the Ent. cloacae (MK) harbouring the cationic factor and the cationic factor independently could induce mortality in the fish, it is likely that the primary causative agent might be the cationic factor. It is plausible that the cationic factor present in the MK isolate is able to convert the isolate into a pathogenic strain, which is otherwise nonpathogenic. Our preliminary experiments with rats and mice have also shown that 
this cationic factor is pathogenic to these animals (data not shown). These results establish that the pathogenesis in fish is primarily because of the cationic factor harboured by the MK isolate.

Even though the enteric bacterial isolates used in this study are from marine environment, it is possible that these must be of human origin as human faecal contamination is prevalent in this lagoon. This study is an example where human enteric bacteria are able to infect fish. It is possible that fish may act as an intermediate vector in transferring this pathogenic bacterium back to humans. The novel cationic factor from MK isolate is intriguing. Work is in progress in this laboratory to biochemically characterize the cationic factor. Our preliminary results show that this cationic factor is pathogenic to mice and this is of health importance. Therefore, the transfer of the cationic factor to other animals, including human beings through bacteria, is of zoonotic importance.

\section{Acknowledgements}

We thank Director, the CIBA, for providing all facilities to carry out this work. Technical assistance rendered by Mr Jagan Mohan Raj is gratefully acknowledged. Dr Thillai Sekar and Dr Stalin Raj are Senior Research Fellows of the National Agricultural Technology Project (NATP). Miss M. Sanjuktha is Junior Research Fellow of CSIR. The financial assistance for this work was provided to the Principal Investigator, TCS, by NATP, New Delhi, India.

\section{References}

Albesa, I., Barnes, A.I. and Paraje, M.G. (2000) Induction of oxidative stress in leukocytes by an Enterobacter cloacae toxin able to form oligomers and binding to proteins. Biochem Biophys Res Commun 274, 649-654.

Aoki, T., Egusa, S. and Watanabe, T. (1973) Detection of R bacteria in cultured marine fish, yellowtails (Seriola quinqueradiata). Jpn J Microbiol 17, 7-12.

Ausubel, F.M., Brent, R., Kingston, R.E., Moore, D.D., Seidman, J.G., Smith, J.A. and Struhl, K. (1987) Current Protocols in Molecular Biology. New York: Wiley.

Barnes, A.I., Paraje, M.G., Orsilles, M and Albesa, I. (2001) Enterobacter cloacae leukotoxin: modulation of reactive oxidant species generated by neutrophils. Luminescence 16, 33-38.

Birnboim, H.C. and Doly, J. (1979) A rapid alkaline extraction procedure for screening recombinant plasmid DNA. Nucleic Acids Res 7, 1513.

Breathnach, A.S., Riley, P.A., Shad, S., Jownally, S.M., Law, R., Chin, P.C., Kaufmann, M.E. and Smith, E.J. (2006) An outbreak of wound infection in cardiac surgery patients caused by Enterobacter cloacae arising from cardioplegia ice. J Hosp Infect 64, 124-128.

Brosius, J., Dull, T.J., Sleeter, D.D. and Noller, H.F. (1981) Gene organization and primary structure of a ribosomal RNA operon from Escherichia coli. J Mol Biol 148, 107-127.

Collee, J.G., Fraser, A.G., Marmion, B.P. and Simmons, A. (1996) Practical Medical Microbiology, 14th edn. New York: Churchill Livingstone.

Davidson, E.W., Rosell, R.C. and Hendrix, D.L. (2000) Culturable bacteria associated with the whitefly, Bemisia argentifolii (Homoptera: aleyrodidae). Fla Entomol 83, 159-171.

Flynn, D.M., Weinstein, R.A., Nathan, C., Gaston, M.A. and Kabins, S.A. (1987) Patients' endogenous flora as a source of "nosocomial" Enterobacter in cardiac surgery. J Infect Dis 156, 363-368.

Gaston, M.A. (1988) Enterobacter: an emerging nosocomial pathogen. J Hosp Infect 11, 197-208.

Geldreich, E.E. and Clarke, N.A. (1966) Bacterial pollution indicators in the intestinal tract of freshwater fish. Appl Microbiol 14, 429-437.

Hansen, G.N., Raa, J and Olafsen, J.A. (1990) Isolation of Enterobacter aglomerans from dolphin fish, Coryphaena hippurus L. J Fish Dis 13, 93-96.

Ish-Horowicz, D and Burke, J.F. (1981) Rapid and efficient cosmid cloning. Nucleic Acids Res 9, 2989.

Janssen, W.A. and Meyers, C.D. (1968) Fish: serologic evidence of infection with human pathogens. Science 159, 547-548.

Kanemitsu, K., Endo, S., Oda, K., Saito, K., Kunishima, H., Hatta, M., Inden, K. and Kaku, M. (2007) An increased incidence of Enterobacter cloacae in a cardiovascular ward. J Hosp Infect 66, 130-134.

Neto, R.J., Yano, T., Beriam, L.O.S., Destefano, S.A.L., Oliveira, V.M. and Rosato, Y.B. (2003) Comparative RFLP- ITS Analysis between Enterobacter cloacae strains isolated from plants and clinical origin. Arq Inst Biol 70367-372.

Nieto, T.P. and Lopez, L.R. (1990) Isolation of Serratia plymuthica as an opportunistic pathogen in rainbow trout, Salmo gairdneri Richardson. J Fish Dis 13, 175-177.

Nordmo, R., Sevatdal, S. and Ramstad, A. (1997) Experimental infection with Vibrio salmonicida in Atlantic salmon (Salmo salar L.): an evaluation of three different challenge methods. Aquaculture 158, 23-32.

Paraje, M.G., Eraso, A.J. and Albesa, I. (2005) Pore formation, polymerization, hemolytic and leukotoxic effects of a new Enterobacter cloacae toxin neutralized by antiserum. Microbiol Res 160, 203-211.

Podschun, R. and Ullmann, U. (1998) Klebsiella spp. as nosocomial pathogens: epidemiology, taxonomy, typing meth- 
ods and pathogenicity factors. Clin Microbiol Rev 11, 589-603.

Sanders, W.E. and Sanders, C.C. (1997) Enterobacter spp.: pathogens poised to flourish at the turn of the century. Clin Microbiol Rev 10, 220-241.

Tan, Y.P., Lin, Q., Wang, X.H., Joshi, S., Hew, C.L. and Leung, K.Y. (2002) Comparative proteomic analysis of extracellular proteins of Edwardsiella tarda. Infect Immun 70, 6475-6480.
Troast, J.L. (1975) Antibodies against enteric bacteria in brown bullhead catfish (Ictalurus nebulosus, LeSueur) inhabiting contaminated waters. Appl Microbiol 30, 189-192.

Vigneulle, M. and Laurensin, B.F. (1995) Serratia liquefaciens: a case report in turbot (Scophthalmus maximus) cultured in floating cages in France. Aquaculture 132, 121-124.

Weisburg, W.G., Barns, S.M., Pelletier, D.A. and Lane, D.J. (1991) 16S ribosomal DNA amplification for phylogenetic study. J Bacteriol 173, 697-703. 